\title{
The Importance of the Application of Non-invasive Techniques in the Study of Wild Animal Reproduction
}

\section{Abstract}

Conservation of biodiversity is one of the major goals of the scientists in many countries. Brazil is one of them and is also well known as the world's largest reserve of biodiversity, which leads to a strategic position in this matter. In the last decade a number of scientific works were published with an increasing participation of Brazilian researchers. One of the keys, besides environmental protection, for the successful conservation of endangered species is reproduction; and the first step is to know how the species function. Traditionally the study of reproductive physiology in wild animals depends on some kind of restrainning, either physical or chemical, which implies different levels of stress. Serial blood sampling necessary to obtain some hormonal profiles are also stressful, unless the animal was trained to accept that procedure, which is hard or even impossible to achieve with some wild species. For that reason some non-invasive techniques were developed, i.e. extraction and measurement of fecal and urinary hormonal metabolites, utilizing radio immune assay (RIA) or enzymatic immune assay (EIA). Different methods of extraction were tested in order to achieve lower costs and reliable results; and validation of the immune assays with different antibodies for a number of wild species were performed with the same purpose. These non-invasive methods for the study of reproductive physiology can be used in free-living and captive wild species as a very useful tool for conservation.

Key Words: non-invasive, fecal hormones, urinary hormones, radio immune assay, enzyme immune assay, wild animals.

\section{Correspondence}

Marcelo Alcindo de Barros Vaz Guimarães

Departamento de Reprodução Animal

Faculdade de Medicina Veterinária e Zootecnia, USP, Cidade Universitária, 05508-900, São Paulo, SP, Brazil.

E-mail: mabvgvra@fmvz.usp.br 
The interest in the environment and its degradation has increased over the last two decades, prompting questions about the cost to humanity of such relentless decline. Nowadays there are myriad institutions - including non-governmental ones that investigate the responsibility for political acts and decisions that result in damage to the environment.

Through various tactics and strategies, professionals with diverse backgrounds coalesce around relevant aspects such as the preservation of biodiversity (animal and vegetal). As a counterpoint to the huge financial interest behind decisions that promote extensive environmental impact in various ecosystems, experts and citizens have searched for responses and alternative ways to prevent the destruction of a genetic reserve of huge potential, not yet fully known, that could yield important answers to significant problems that afflict mankind.

Among institutions responsible for generating scientific information that assists in conservation of nature are the Zoo Parks, Universities, Botanic Gardens and Research Institutes. The synergetic work of such institutions has produced works of research throughout the planet that have resulted in success that is significant though modest compared to the gigantic scale of the problems.

Some specific examples are: the American bison (Bison bison Hamilton - Smith, 1827), at present out of extinction risk; the Siberian tiger (Panthera tigris altaica Oken, 1816); the sea otter (Enhydra lutris Fleming, 1822); the black-footed-ferret (Mustela nigripes Lineu, 1758) and the golden lion tamarin (Leontopithecus rosalia Lesson, 1840), the latter being the object of a successful international project that obtained success not only in the captive reproduction of the species but also its reintroduction into nature, a project that depended on the participation of Brazilian experts.

Not by chance, the examples mentioned above are also subjects of the combined work of several institutions such as zoos, universities and research institutes. In countries such as England, South Africa, Germany and mainly the United States, there are advanced research centers where studies of wild animals are developed in areas such as: immunology, pharmacology, physiology, pathology, infectious and parasitic illnesses, including zoonosis, organ transplants, molecular biology, endocrinology, behavior and artificial reproduction.

In this context we can notice the importance of this multidisciplinary work that fights simultaneously for the conservation of species "in situ", with field work and "ex situ", reproducing in captivity the species to be studied and reintroduced. The importance of such work does not reside only in the conservationist aspect but also, and not least importantly, relates to biomedical research aspects that involve problems related directly to human health. With this focus we can mention the types of research that are accomplished by using wild animals as a biological model, i.e.: the search for the cure or prevention of AIDS (acquired immune deficiency syndrome), as well as works regarding transplants, genetic diseases, the production of vaccines against malaria and many others. 
These examples demonstrate that the extinction of any specie may represent a priceless loss to humanity, as it takes with it all its genetic information and biological characteristics that could be vital to the maintenance of biodiversity in addition to an unknown number of fundamental answers for the maintenance of life on this planet.

Wild animal reproduction in captivity is a fundamental tool that enables us to carry out research without withdrawing any exemplar from nature. In this context, zoos and conservationist nurseries assume a prominent role as they are recognized as genuine genetic banks of wild species and work with reproduction as a primary objective.

It is common knowledge that several Brazilian wild species belong to a list of animals threatened with extinction and that many of these present reproductive difficulties in captivity, despite appropriate handling and feeding. These conditions demand measures that aim to improve the reproductive performance of such animals.

With this purpose, we examine, in the context of the reproductive physiology of different species, ways of adapting artificial reproductive techniques to anatomical, physiological and handling characteristics for each of them (Short, 1968; Wildt \& Bush, 1984; Holt \& Moore, 1988; Durrant, 1990; Hearn, 1994).

Traditionally, the methods used in these studies are the non-invasive ones, which for the animal implies physical or chemical restraint, as well as the use of injections and multiple blood collection. In some cases such as in artificial insemination, electroejaculation or embryo transfers, such procedures are inevitable. In the case of hormonal studies, during recent years a strong trend arose that commends the adoption of noninvasive techniques that would avoid the restraint of the animal, for instance in serial blood collection. The stress generated by the restraining procedure, besides compromising animal health, would render multiple and consecutive collection unfeasible, although it would certainly increase the hormonal parameters to be measured by the action of augmented cortisol over the hypothalamus-hypophysis-gonad axis with a consequent effect on the level of sexual steroids and gonadotrofins (Line et al., 1987; Sapolsky \& Krey, 1988; Carlstead et al., 1992; Mendoza et al., 1994; Jurke et al., 1997; Whitten et al., 1998; Möstl \& Palme, 2002).

Among these non-invasive techniques include the extraction and dosage of hormones or their metabolites from feces and urine, which can be collected daily or several times a day with no kind of physical or chemical restraint; moreover they can be collected from free-range individuals, which enables long term serial studies with no interference of stress effects.

Therefore, a number of authors have been studying reproductive endocrinology of different wild species through extraction and dosage of steroid metabolites from feces and urine (Kasman et al., 1985; Chaudhuri et al., 1988; Monfort et al., 1990; Bamberg et al., 1991; Gross et al., 1991; Lasley \& Kirkpatrick, 1991; Monfort et al., 1991; Paul-Murphy et al., 1991; Knox et al., 1992; Brown et al., 1993; Brown et al., 1994; Brown et al., 1995; Graham et al., 1995; Papageorge et al., 1995; Shaw et al., 1995; 
Stavisky et al., 1995; Walzer \& Schwarzenberger, 1995; Morais et al., 1996; Berkeley et al., 1997; Heistermann et al., 1997; Radcliffe et al., 1997; Robeck et al., 1997; Garrott et al., 1998). Non-human primates - as per their phylogenic proximity to mankind - are especially important as a research biological model for studies connected to physiology, immunology, pharmacology, endocrinology and reproduction. For this reason several papers involving reproduction studies in non-human primate species through non-invasive methods have been published (Shideler et al., 1985; Wasser et al., 1988; Ziegler et al., 1989; Masters \& Markham, 1991; French et al., 1992; Shideler et al., 1993; Wasser et al., 1993; Asa et al., 1994; Jurke et al., 1994; Pryce et al., 1994; Bellem et al., 1995; Brockman et al., 1995; Heistermann \& Hodges, 1995; Heistermann et al., 1995; Kuederling et al., 1995; Pryce et al., 1995; Oerke et al., 1996; Ialeggio et al., 1997; Strier \& Ziegler, 1997; Ziegler et al., 1997; Guimarães et al., 2002).

Always seeking resource optimization and simplification of techniques without jeopardizing the quality of the results, recent works involving extraction and dosage of hormonal metabolites in neo-tropical primates showed that fecal progestin (a group of progesterone metabolites) dosage is the most effective non-invasive method of studying the ovary cycle of these species (Strier \& Ziegler, 1997; Guimarães et al., 2002). This technique enabled the characterization of follicular and luteinizing phases, as well as permitted the determination of the peri-ovulation period and the estimated ovulation day (Strier \& Ziegler, 1997; Guimarães et al., 2002). Besides reflecting the variation of progesterone plasma levels in a few hours interval (Adlercreutz \& Martin, 1980; Ribeiro, 1994), fecal progestin dosages, since they present a similar molecular and antigen structure among the species, also possess the advantage of permitting the utilization of traditional laboratory methods of hormone dosage, such as the radio-immuno-assay, using antiprogesterone antibody produced in laboratory animals (Ribeiro, 1994; Guimarães et al., 2002).

The methods of fecal progestin extraction and dosage, initially complex and lengthy, demanded purification through chromatographic separation and analysis and also the identification and dosages of metabolites (Risler et al., 1987; Wasser et al., 1988). Due to the high cost and the complexity in executing such techniques, several researchers accomplished comparative studies between performance of sophisticated methods and simple techniques of reduced costs, producing results that allow the implementation of projects with a large number of samples at reduced budgets (Meirelles, 1993; Strier \& Ziegler, 1994; Ziegler et al., 1996; Strier \& Ziegler, 1997).

Information obtained through non-invasive methods are of great utility to the planning of reproduction programs, such as the choosing of females with an adequate pattern of cycles to dictate the best moment for an artificial insemination or even optimizing parameters for insemination through natural breeding.

Another relevant aspect is the applicability of this method to field studies where it becomes possible to verify the reproductive condition or even the phase of the 
ovary cycle in free-range females. These data are vital to the study of social structure, hierarchic interrelation, family and reproductive strategy which a specie adopts for the purpose of adaptation.

No less important than the aforementioned reasons, these techniques also are ethically justified. Increasingly, the conscientiousness of researchers must be applied to minimize the agony of animals used in experiments, seeking alternative methods that reduce the stress caused by contention and handling, avoiding for instance the fear and pain caused by many of the traditional invasive methods (Wolfensohn \& Lloyd, 1998).

The Department of Animal Reproduction of Zootechnics and Medical Veterinary Faculty of the University of São Paulo, currently are developing a line of research in reproductive endocrinology, using non-invasive methods. This line of research is essentially composed of projects that utilize different techniques of extraction and dosages of sexual steroid hormones from fecal metabolites, with several approaches in different species such as: Amazonian manatee (Trichecus ininguis), jaguarundi (Herpailurus yagouaroundi), jaguar (Panthera onca), ocelot (Leopardus pardalis), brown capuchins (Cebus apella), black howler monkey (Alouatta caraya), blue-fronted parrot (Amazona aestiva), golden hamster (Mesocricetus auratus), Guinea pig (Cavia porcellus), maned wolf (Chrisocyon brachyurus), African lion (Panthera leo) and fallow deer (Dama dama).

From basic physiological information obtained through these non-invasive techniques, projects are being developed to study characteristics of the ovarian cycle, seasonal variation occurrences, ovulation detection, pregnancy diagnosis, parturition proximity, sex identification of monomorphic species, efficiency of contraceptive methods, purging methods and identification of different hormone metabolites, as well as the influence of animal well being on reproductive performance, stress effects and the interrelation between hormone levels and reproductive behavior patterns (behavioral endocrinology).

\section{References}

Adlercreutz H, Martin F. Biliary excretion and intestinal metabolism of progesterone and estrogens in man. J Steroid Biochem 1980;13:231-44.

Asa CS, Fischer F, Carrasco E, Puricelli C. Correlation between urinary pregnanediol glucuronide and basal body temperature in female orangutans, Pongo pygmaeus. Am J Primatol 1994;34: 275-81.

Bamberg E, Möstl E, Patzl M., King GJ. Pregnancy diagnosis by enzyme immunoassay of estrogens in feces from nondomestic species. J Zoo Wildlife Med 1991;22(1):73-7.

Bellem AC, Monfort SL, Goodrowe KL. Monitoring reproductive development, menstrual cyclicity, and pregnancy in the lowland gorilla (Gorilla gorilla) by enzyme immunoassay. J Zoo Wildlife Med 1995:26;24-31.

Berkeley EV, Kirkpatrick JF, Schaffer NE, Bryant WM, Threlfall, WR. Serum and fecal steroid analysis of ovulation, pregnancy, and parturition in the black rhinoceros (Diceros 
bicornis). Zoo Biol 1997;16:121-32.

Brockman DK, Whitten PL, Russel E, Richard AF, Izard MK. Application of fecal steroid techniques to the reproductive endocrinology of female verreaux's sifaka (Propithecus verreauxi). Am J Primatol 1995;36:313-25.

Brown JL, Wasser SK, Howard JG, Wells S, Lang K, Collins L, Raphael B, Schwartz R, Evans M, Hoyt R, Volk T, Wildt DE, Graham LH. Development and utility of fecal progesterone analysis to assess reproductive status in felids. In:Annual Conference of the American Association of Zoo Veterinarians, Saint Louis. Proceedings 1993:273-6.

Brown JL, Wasser SK, Wildt DE, Graham LH. Comparative aspects of steroid hormone metabolism and ovarian activity in felids, measured noninvasively in feces. Biol Reprod 1994;51:776-86.

Brown JL, Wildt DE, Graham LH, Byers AP, Collins L, Barret S, Howard JG. Natural versus chorionic gonadotropin-induced ovarian responses in the clouded leopard (Neofelis nebulosa) assessed by fecal steroid analysis. Biol Reprod 1995:53;93-102.

Carlstead K, Brown JL, Monfort SL, Killens R, Wildt DE. Urinary monitoring of adrenal responses to psychological stressors in domestic and nondomestic felids. Zoo Biol 1992;11:165-76.

Chaudhuri M, Kleiman DG, Wildt DE, Bush M, Frank ES, Thau RB. Urinary steroid concentrations during natural and gonadotrophin-induced oestrus and pregnancy in the giant panda (Ailuropoda melanoleuca). J Reprod Fert 1988;84:23-8.

Durrant BS. Semen collection, evaluation, and cryopreservation in exotic animal species:maximizing reproductive potencial. Ilar News 1990;32(1):2-10.

French JA, Degraw WA, Hendricks SE, Wegner F, Bridson WE. Urinary and plasma gonadotropin concentrations in golden lion tamarins (Leontopithecus rosalia rosalia). Am J Primatol 1992;26:53-9.

Garrott RA, Monfort SL, White PJ, Mashburn KL, Cook JG. One-sample pregnancy diagnosis in elk using fecal steroid metabolites. J Wildlife Dis 1998;34(1):126-31.

Graham LH, Goodrowe KL, Raeside JL, Liptrap RM. Non-invasive monitoring of ovarian function in several felid species by measurement of fecal estradiol-17b and progestins. Zoo Biol 1995;14:223-37.

Gross TS, Tharnish T, Rodden M. Fecal steroid analyses as na assessment of reproductive function in the maned wolf (Chrysocyon brachyurus). Annual Conference of the American Association of Zoo Veterinarians. Calgary, Proceedings 1991:387-9.

Guimarães MABVG, Oliveira CA, Ribeiro EAA, Rosa e Silva AAM, Franci CR, Batista SAZ, Barnabé RC. Monitoring ovarian function in the Capuchin Monkey (Cebus apella) using fecal and urinary hormone analyses. The Second International Symposium on Assisted Reproductive Technology for the Conservation and Genetic Management of Wildlife. Omaha, Proceedings 2002:290.

Hearn JP. New world primates research in human reproductive health. Am J Primatol 1994;34:11-7. 
Heistermann M, Finke M, Hodges JK. Assessment of female reproductive status in captivehoused hanuman langurs (Presbytis entellus) by measurement of urinary and fecal steroid excretion patterns. Am J Primatol 1995;37:275-84.

Heistermann M \& Hodges JK. Endocrine monitoring of the ovarian cycle and pregnancy in the saddle-back tamarin (Saguinus fuscicollis) by measurement of steroid conjugates in urine. Am J Primatol 1995;35:117-27.

Heistermann M, Trohrsch B, Hodges JK. Assessment of ovarian function in the African Elephant (Loxodonta africana) by measurement of 5a-reduced progesterone metabolites in serum and urine. Zoo Biol 1997;16: 273-84.

Holt WV, Moore DM. Semen banking - is it now feasible for captive endangered species? Oryx 1988;22(3):172-8.

Ialeggio DM, Ash R, Bartow ST, Baker AJ, Monfort SL. Year-round urinary ovarian steroid monitoring in a clinically healthy captive owl-faced guenon (Cercopithecus hamlyni). In: Annual Conference of the American Association of Zoo Veterinarians, Houston, Proceedings 1997:232-4.

Jurke MH, Pryce CR, Döbeli M, Martin RD. Non-invasive detection and monitoring of pregnancy and the post-partum period in Goeldi's monkey (Callimico goeldii) using urinary pregnanediol-3a-glucuronide. Am J Primatol 1994;34:319-31.

Jurke MH, Czekala NM, Lindburg DG, Milliard SE. Fecal corticoid metabolite measurement in the Cheetah (Acinonyx jubatus). Zoo Biol 1997;16:133-47.

Kasman LH, McCowan B, Lasley BL. Pregnancy detection in tapirs by direct urinary estrone sulfate analysis. Zoo Biol 1985;4:301-6.

Knox WM, Miller KV, Collins DC, Bush PB, Kiser TE, Marchinton RL. Serum and urinary levels of reproductive hormones associated with the estrous cycle in white-tailed deer (Odocoileus virginianus). Zoo Biol 1992;4:301-6.

Kuederling I, Evans CS, Abbott DH, Pryce CR, Epple G. Differential excretion of urinary oestrogen by breeding females and daughters in the red-belied tamarin (Saguinus labiatus). Folia Primatol 1995;64:140-5.

Lasley BL, Kirkpatrick JF. Monitoring ovarian function in captive and free-ranging wildlife by means of urinary and fecal steroids. J Zoo Wildlife Med 1991;22(1):23-31.

Line SW, Clarke AS, Markowitz H. Plasma cortisol of female rhesus monkeys in response to acute restraint. Lab Prim Newsletter 1987;26(4):1-4.

Masters AM \& Markham RJ. Assessing reproductive status in orang-utangs by using urinary estrone. Zoo Biol 1991;10:197-207.

Meirelles CF. Controle reprodutivo em capivaras (Hydrochoerus hydrochaeris bydrochaeris Lineu, 1766) através da determinação de progesterona nas fezes. Thesis, Escola Superior de Agricultura Luiz de Queirós, Universidade de São Paulo, Brazil 1993.

Mendoza SP, Capitanio JP, McChesney MB, Lerche NW. Stress, hipothalamic-pituitaryadrenal activity and leucocyte levels. Am J Primatol 1994;33(3):228-9.

Monfort SL, Wemmer C, Kepler TH, Bush M, Brown JL, Wildt DE. Monitoring ovarian 
function and pregnancy in eld's deer (Cervus eldi thamin) by evaluating urinary steroid metabolite excretion J Reprod Fertil 1990;88:271-81.

Monfort SL, Martinet C, Wildt DE. Urinary steroid metabolite profiles in female Père David's deer (Elaphurus davidianus). J Zoo Wildlife Med 1991;22(1):78-85.

Morais RN, Moreira N, Moraes W, Mucciolo R, Lacerda O, Gomes MLF, Swanson WF, Graham LH, Brown JL. Testicular and ovarian function in South American felids assessed by fecal steroids. In: Annual Conference of the American Association of Zoo Veterinarians. Puerto Vallarta, Proceedings 1996:561-5.

Möstl E, Palme R. Hormones as indicators of stress. Domest Anim Endocrin 2002;23:67-74.

Oerke AK, Einspanier A, Hodges JK. Noninvasive monitoring of follicle development, ovulation, and corpus luteum formation in the marmoset monkey (Callithrix jacchus) by ultrasonography. Am J Primatol 1996;39:99-113.

Papageorge S, Wasser SK, Foley C, Brown JL. Fecal steroid analysis: validation of extration and radioimmunoassay for estradiol and progestogens in African Elephants (Loxodonta africana) and analysis of fecal samples utilizing a validated method. In: Annual Conference of the American Association of Zoo Veterinarians. East Lansing, Proceedings 1995;393.

Paul-Murphy J, Tell L, Bravo W, Fowler ME, Lasley BL. Urinary steroid evaluations to monitor ovarian function in exotic ungulates: VIII. Correspondence of urinary and plasma steroids in the llama (Lama glama) during nonconceptive and conceptive cycles. Zoo Biol 1991;10:225-36.

Pryce CR, Schwarzenberger F, Döbeli M. Monitoring fecal samples for estrogen excretion across the ovarian cycle in Goeldi's monkey (Callimico goeldii). Zoo Biol 1994;13:219-30.

Pryce CR, Schwarzenberger F, Döbeli M, Etter K. Comparative study of oestrogen excretion in female new world monkeys: an overview of non-invasive ovarian monitoring and a new application in evolutionary biology. Folia Primatol 1995;64:107-23.

Radcliffe RW, Czekala NM, Ososfsky A. Combined serial ultrasonography and fecal progestin analysis for reproductive evaluation of the female White rhinoceros (Ceratotherium simum simum): preliminary results. Zoo Biol 1997;16:445-56.

Ribeiro EAA. Uma análise da relação entre o comportamento reprodutivo e os níveis de progestinas fecais em um grupo silvestre do mico-leão-dourado (Leontopithecus rosalia). PhD Thesis, Instituto de Biociências, USP, São Paulo, Brazil, 1994.

Risler L, Wasser SK, Sackett GP. Measurement of excreted steroids in Macaca nemestrina. Am J Primatol 1987;12:91-100.

Robeck TR, Fitzgerald LJ, Hnida JA, Turczynski CJ, Smith D, Kraemer DC. Analisys of urinary progesterone metabolites with behavioral correlation in guenther's dik-dik (Madoqua guentheri). J Zoo Wildlife Med 1997;28(4):434-42.

Sapolsky RM, Krey LC. Stress induced suppression of luteinizing hormone concentrations in wild baboons: role of opiates. J Clin Endocr Metab 1988;66(4):722-6.

Stavisky R, Russel E, Stallings J, Smith EO, Worthman C, Whitten PL. Fecal steroid 
analysis of ovarian cycles in free-ranging baboons. Am J Primatol 1995;36:285-97.

Shaw HJ, Green DL, Sainsbury AW, Holt WV. Monitoring ovarian function in scimitarhorned oryx (Oryx dammah) by measurement of fecal 20a-progestogen metabolites. Zoo Biol 1995;14:239-50.

Shideler SE, Mitchell WR, Lindburg DG, Lasley BL. Monitoring luteal function in the lion-tailed macaque (Macaca silenius) through urinary progesterone metabolite measurements. Zoo Biol 1985;4:65-73.

Shideler SE, Ortuño A, Morán FM, Moorman EA, Lasley BL. Simple extraction and enzyme immunoassays for estrogen and progesterone metabolites in the feces of Macaca fascicularis during non-conceptive and conceptive ovarian cycles. Biol Reprod 1993;48:1290-8.

Short RV. The reproductive physiology of exotic animals. Fertil Steril 1968;19(1):30-6.

Strier KB \& Ziegler TE. Insigths into ovarian function in wild muriqui monkeys (Brachyteles arachnoides). Am J Primatol 1994;32:31-40.

Strier KB \& Ziegler TE. Behavioral and endocrine characteristics of the reproductive cycle in wild muriqui monkeys (Brachyteles arachnoids). Am J Primatol 1997;42:299-310.

Walzer C \& Schwarzenberger F. Estrous cycle induction in a white rhinoceros (Ceratotherium simum simum) and concomitant EIA fecal progestogen analysis. In: Annual Conference of the American Association of Zoo Veterinarians. East Lansing, Proceedings 1995:365-8.

Wasser SK, Risler L, Steiner RA. Excreted steroids in primate feces over the menstrual cycle and pregnancy. Biol Reprod 1988;39:862-72.

Wasser SK, Thomas R, Nair PP, Guidry C, Southers J, Lucas J, Wildt DE, Monfort SL. Effects of dietary fibre on faecal steroid measurements in baboons (Papio cynocephalus). J Reprod Fertil 1993;97:569-74.

Whitten PL, Stavisky R, Aureli F, Russel E. Response of fecal cortisol to stress in captive chimpanzees (Pan troglodytes). Am J Primatol 1998;44:57-69.

Wildt DE, Bush M. Reproductive physiology studies in zoological species: concerns and strategies. Zoo Biol 1984;3:363-72.

Wolfensohn S, Lloyd M. Handbook of laboratory animal manegement and welfare. Oxford:Blackwell Science 1998.

Ziegler TE, Sholl SA, Scheffler G, Haggerty MA, Lasley BL. Excretion of estrone, estradiol, and progesterone in the urine and feces of the female cotton-top tamarin (Saguinus oedipus oedipus). Am J Primatol 1989;17:185-95.

Ziegler TE, Sheffler G, Wittwer DJ, Schultz-Darken N, Snowdon CT, Abbott DH. Metabolism of reproductive steroids during the ovarian cycle in two species of callithricids, Saguinus Oedipus and Callithrix jacchus, and estimation of the ovulatory period from fecal steroids. Biol Reprod 1996;54:91-9.

Ziegler TE, Santos CV, Pissinati A, Strier KB. Steroid excretion during the ovarian cycle in captive and wild muriquis (Brachyteles arachnoids). Am J Primatol 1997;42:311-21. 
